Warszawskie Studia Pastoralne UKSW

Rok X 2015 Nr 4 (29)

Ks. Jan Kazimierz PrzybyŁowski (UKSW)

\title{
POVERTY AND SOCIAL EXCLUSION IN THE LIGHT OF SOCIO-THEOLOGICAL PERSPECTIVE
}

The words of Leon the Great's became the direct motive for undertaking researches in order to answer the question: what is the relation between poverty and social exclusion ${ }^{1}$. One could wonder who were the Poor, that Jesus was talking about, while saying: «The Blessed Poor», however He hadn't marked how this poverty should be understood." It could therefore be seemed that in order to achieve the Kingdom of Heaven such insufficiency is enough that many people receive as a result of permanent and tiresome necessity.

However by saying „The blessed are poor in spirit”, the Lord had pointed out that the Kingdom of Heaven would be offered to those, who are distinguished by inner humility rather than by the lack of outer properties ${ }^{2}$.

Two kinds of poverty are explicitly pointed out by those words; 1) poverty caused by permanent and tiresome necessity (social size), and 2) poverty for the Kingdom of Heaven (theological size). Not the lack of material possessions but inner humility decides on this basic fundamental division. Such division doesn't take place outside, but its line takes place inside the man.

1 The term of social exclusion is often identified mistakenly with the term of social exclusion. Despite both terms are related, the latter one is much wider, for apart from low earnings, it also pays attention to other factors causing exclusion of units from functioning in social life. Their interdependence is of a feet-back nature, that is poverty may cause exclusion, but it may be its effect a well.

2 St. Leaon the Great On blessings (sermon 951 - 2), Liturgy of Hours,v.4,p.155. 
A basic existential topic may appear here; what ought to be considered in the first place; To provide for the basic needs of the men, or rather the topic of the Kingdom of Heaven ? This topic may be solved easily; provision for the basic needs of the man is a priority, and no-one has the right, even in favour of the most sublime ideas, to refuse the needy to appease their hunger, thirst, to ensure them accommodation units and fulfil or execute their basic life needs. However pointing out the necessity of making fundamental decisions in their private life is a completely different matter. It is the man himself who can determine all his priorities in life; whether it is the outer enrichment or the way towards the humility in the Kingdom of Heaven ? Finally it doesn't solve about the renouncement of the outer goods, but it is the indication to the final target and the way towards its achievement. It may be said that poverty has two basic sizes; sociological and theological; the sociological shows the poverty from the side of the nation, while the theological from the man's one'.

\section{Sociological and theological sizes of poverty}

Poverty has many meanings. It means lack of sufficient material resources in sociological sizes. Such poverty exists in many painful occurrences such as; insufficient funds for existence, lack of necessary medical care, homelessness or hard living conditions, pushing the weakest to the margin of society, unemployment, tragic consequences of wars, exploitation and social inequality, loneliness and forgetting about the elderly and the sick, economic migration, split off families, alcoholism, drug addiction and other kinds of violence. Sociological poverty in any kind (sociological, economic, economical, cultural and political) humiliates the man, abases his dignity and deforms the whole mankind.

Sociological poverty as well as the utmost social, cultural, economical inequalities are present the world-wide despite technological and scientifical progress. It appears however that technological one, despite it serves the civilization's development doesn't solve the majority of social problems, doesn't improve the situation of many nations and often doesn't influence on the improvement of individual men's' 
situation. It becomes more and more obvious that civilization progress increases or simply strengthens unjust inequalities.

The most horrifying result of poverty is decline in morality and spirit what pays with the loss of hope for the future. The poverty in spirit can be especially seen in rich countries, where man can satisfy his material needs without rejection of his basic values. However every man is seeking in the depth of his heart for value, that would fulfil the point of his existence. It is a need to appear in questions that demand answers from the man. The basic question is; Is there any point in life ? Where does the humans' life tends to ? Everything what goes on around the man and cannot be explained recalls dramatic questions about the point of life. However the first and absolutely unquestionable truth of human's existence is the inevitable necessity of death, so this is why the man wants to know whether the death will be the final point of his life or just it will be the beginning of a new life? All philosophers, theologists and ordinary people ask such questions searching for something deepest, what could be a ground for human's and the world's existence ${ }^{3}$.

The poverty in theological size is the necessary condition in searching for the human's point of life. First it 'means the inner distance towards material goods, that allow to share them with others. It is the spirit of poverty that decides about it, which is like a fruit of life's attitude, inspired by social love and solidarity ${ }^{4}$.

The spirit of poverty despite spirit's reality, requires satisfaction within some specific actions, what means sharing its goods with other people. Spirit of poverty ought to be within all people, for it is the only way of practicing love and solidarity. It ought to be mentioned

${ }^{3}$ John Paul II, Enciclics Fides et ratio, 26-27

4 Catholics Church's catechism states first, that the demand of human's life dignity respectation in economic field means that the virtue of moderation ought to be practiced, in order to limit the attachment to the goods of the world; the virtue of justice in order to respect the twins' rights and to give him what he deserves; virtue of solidarity - according to the golden principle and following the example of "Christ who being rich „ became poor for us in order to „make us rich with his property (2 Kor. 8,9), (KKK 2407). 
however, that the spirit of poverty doesn't mean the rejection of properties ${ }^{5}$. But gives an opportunity of gaining the virtue of moderation in material goods' using.

The poverty's spirit practice may have an impact on human's perceiving of some values of civilization progress, economic development and proper use of the human's work fruits. Due to the fact that in contemporary world the economic growth has grown the most and became a base of the progress of civilization, particularly within human and social matters, it is the spirit of poverty, that should play more and more considerable role. Poverty in theological size gives an inner freedom into the man, owing which he becomes sensitive and is capable to understand the human himself and the nature of his life, closely related with material conditions. Contemporary man shall have the right, and in some conditions just a duty to give proper and sometimes even strict judgement on the wealthy and comfortable life, to decide when and how to help generously to the needy or to undertake such actions, that the wealth doesn't become a reason of conflicts between people but instead it could serve to the social prospects, according to just rules and was subscribed according to social justice and interhuman solidarity owing to theological poverty ${ }^{7}$.

People that are practicing theological poverty are able to give well-advised judgment on everything what concerns outer goods that are necessary for every-day life „, that ought to be however less priced than spiritual goods and give help eternally and noble regarding that. Firstly, nevertheless the science, technique and particularly human's

${ }^{5}$ Loyalty to the spirit doesn't mean practicing radical poverty which means rejecting all properties or even a suppression of human's right to the property. Magisterium of the Church damned many times those who were in favour of such necessity (Com-p. Denz 760, 930n, 1097) and have tried to direct such practice towards moderation.

${ }^{6}$ Love is the coronation of every virtue. It means both; love towards a person (service towards other person) and love in spiritual size which allows to exceed all borders of time and space and enables the needy help through a prayer and offering in their intention.

7 John Paul II Encilics Ecclesiam suam, 55. 
work arise our interests the most, and their fruit, that is bread; in both circumstances; for the table and for the altar is decided to be the saint one. Church's education is of the kind that doesn't leave any doubts regarding this ${ }^{8}$.

The above clear instructions of John Paul II ought to be joined with the right and prophetic diagnosis of present situation where the fruit of the civilizational progress are menaced the most. „So what [...] is left from this idyllic and real progress ? First of all we can see that the wars are harassing [...], that social, religious, racial discrimination continues, even increases. We can notice [...] that humans seem to consolidate in firstly psychological and political attitudes of past times. [...]. The supremation of economical interests comes back, the habit of hatred returns with an easy overuse of the weaker exploitation [...] as well as the fight of social classes. International and domestic wars rebirth this way. Competition of national prestige and political power comes back; and again there exists severe conflicts of repugnant ambitions, established irremovable particularism of races and ideological systems; tortures and terrorism, crime and violence treated as a noble flame, not taking fires into consideration. Peace is perceived as a clear balance of powerful forces and fearful armaments. A shiver of fear can be felt while thinking that some awful mistakes can lead to unbelievable and unstopped wars' conflagration break-out. What is going on then ? What hadn't we fulfilled or what is the lack of?' each proper diagnosis brings an important conclusion;

\section{poverty and social exclusion come from one source}

The term „social exclusion” in social teaching of the Church maybe replaced with 'social discrimination” or „degradation”. It seems that such terminological variety is needed in order to indicate the multidirectionality of analyzing or interpreting the reasons and effects of such abnormalities appearing within social life. If we add „poverty”

8 John Paul II Enciclics Ecclesiam suam, 55.

9 John Paul II Manifesto for the Day of Peace Every man is my brother 14 XI 1970. 
to the above terms - it only directs next researches into formal aspect, yet the main problem remains the same.

Exclusion, discrimination or degradation point explicitly towards man, whose existential situation and actions reflect his personal and spiritual inside. The Constitution ministry teaching about the Gaudium et spes shows such a construction. The council fathers emphasizes in it that there are different physical capabilities and varied moral and intellectual powers between people. However all forms of discrimination regarding basic rights of the man (social, cultural or concerning sex, race, carnation, social status, religion or language) should be overcome and removed, for it is contrary to the God's right. Such actions ought to be undertaken which could ensure more human and fair life conditions to the people. All economic and social inequalities cause depravation and are in contrast with social justice, equality, human's dignity as well as social and international peace ${ }^{10}$.

John Paul II Had confirmed this diagnosis in Apostols' Letter Novo millenio neunte. He emphasized that cotemporary world functions in contradictions related to cultural, economic and technical development that enables great possibilities to some chosen ones, while leaves millions of people on the edge of progress and forces them to cope with life conditions which insult human's dignity.

The Pope simply asks; How it is possible that here exists people who die of hunger, are fated to illiteracy, with no access to the basic medical care, deprived their homes in which they could find some shelter ${ }^{11}$.

The problem of poverty not only wasn't solved in contemporary world, but still extends and makes new forms also among rich people, who are threatened by utter desperation coming from the feeling of life's nonsense, danger of drugs addiction, abandonment in older age or during sickness, social degradation and discrimination ${ }^{12}$. Such situation shows that

10 KDK 29.

11 John Paul II Apostol's Letter Novo Milennio ineunte, 50.

12 John Paul II Apostol's Letter Novo Milennio Inveunte,50. 


\section{poverty and social exclusion lead towards the same effects}

Man's degradation or auto degradation as a person and breach of his dignity are the main effects of poverty and social exclusion. Depersonalizing effects consolidate social inequalities and addict human to himself and to all conditions he exists in. It locks human from the reality of spiritual life and leads him to moral decline, since it weakens the God's law which doesn't allow egoism and hatred, lie and attempt to destroy the human. Every kind of poverty and social exclusion lead the men to slavery causing degradation of his dignity. It should also be mentioned that methods of human's degradation became more subtle nowadays, what means more menacing. This is why a special care on shaping human consciences and making them more sensitive towards basic values; life, good, freedom, truth, love, justice and human solidarity is needed.

However some kind of sensitiveness in human's degradation may be noticed in the sphere of pleasure and love. If human under the influence of advertisement deepens himself into delusive and trivial pleasures, what means he tends to inner emptiness that body's reactions remain inside the man; harlotry, impurity, profligacy [...] alcohol abuse, junkets, etc. (Ga 5 19,2).

Also such pleasures , which man is seeking in possessing or immoderate using of wealth, in luxury, intending to power, that means such possessions and fascination of the Earth's goods, that may change into blindness of the mind - may be added to those false ones"13.

However it is a $\sin ^{14}$ that is the worst effect of poverty and social exclusion. St. Paul had described this kind of degradation in his Letter to Romans. Watching the moral decline of his times, he wrote that people when forgetting about the God „had sunk into degradation in their thoughts and their brainless hearts became dimmed „. (Rz 1,21). „They had replaced the God's Truth with a lie and they had a cult of zadatry instead to serve the Creator [...] And due to the fact that

\footnotetext{
13 John Paul II Catechesis The Holy Ghost - source of real joy 19 VI 1991, 1.

14 The sin is ", self-love until the contempt of the God" St. Augustin, De Civitate Dei, $14,28$.
} 
they hadn't even considered getting to know the God, He left them to their fate of their useless brains, because they had been doing what was not right". (Rz 1,25.28)

The man as a person and a social subject suffers from poverty and social exclusion the most, since they deprive him from participation in the life of commune, independently of him. Due to social injustice and lack of interhuman solidarity, the poor person becomes excluded from economic, cultural and political life and also from the access to the common good of the nation he lives in. Social effects of poverty and social exclusion are apparent among the handicapped, mentally sick, addicted, unemployed, leaving reformatories, lonely mothers, victims of home violence, uneducated, homeless, refugees and professional minority members, youth from shelters and pathological families.

Particularly painful effects of poverty and social exclusion are also apparent among families that live in poverty from above reasons, families that are not able to feed their kids or give them any conditions to normal psychical, mental or spiritual growth or assure them some access to education. Many families cope with harsh living conditions. It is often related to prolonged parents' unemployment. Children and youth suffer the most, hanging out in the streets without any care and often become alcohol or drug addicted or simply join the gangs. There are many married couples that have to cope with mental problems and crisis within their families. Such social problems become a reason of the families break-up ${ }^{15}$.

The church knows about all those problems but it cannot be engaged into them for social justice ought to be pursued by politics. The Church's task is indirect and is based on purifying brains and ensuring moral forces, because neither fair structures nor their long-term functioning can do without them. Due to those facts the Church is awaiting help from

15 John Paul II, Manifesto to the Lent 3 IX 1993,4. 


\section{pastoral theology in solving poverty and social exclusion problems.}

Firstly it means such an activation of the community's faithful members that they could undertake the task of the nation's humanization on the base of he Gospel's Truth teaching and they could actively participate in solving social problems including poverty and social exclusion. Christians who are properly formed and competent may take part in better respectation of every man according to the rule of common help. The economic, economical also civilizational growth with consideration of what is human's is the basic principle in solving those problems, for every man, human's society and global population ought to be priced ${ }^{16}$.

Nowadays the forms of human's degradation became very subtle, what means more dangerous. Due to secularity of everyday life, contemporary Christians find it more difficult to join the Gospel's Truth teaching with everyday experience. "the difficulty of surviving in personal faith in Jesus increases in such cultural and social aspects where Christian's' conception of life in being constantly menaced; it is easier within many public spheres to declare being an agnostic, than the faithful one; it seems that unbelief is something natural, while belief requires social credibility that is neither obvious nor foreseen ${ }^{17}$.

More and more noticeable is also aiming to impose anthropology without God upon people, what results in a fact that the man is seemed to be , an absolute center of reality, forcing him to take the God's place over what is against the nature, and forgetting that not the human creates the God, but the God creates the human" In consequence a wide space for nihilism in a field of philosophy, also relativism in the field of morality and knowledge, pragmatism or even cynical hedonism in a structure of every day's life had opened ${ }^{18}$.

\footnotetext{
16 See L.J. Lebert, Dynamise concrete du development, Paris 1961, p. 28.

17 John Paul II, Apostol's Adhortation Ecclesia in Europa, 7.

18 Bishops Council, Second Special Gatherings devoted Europe, Relatio ante disceptationem 1,1,2” L'Observatore Romano, 3 X 1999 p.6 (daily).
} 
In this new situation researches conducted in the field of pastoral theology may play an important role. It deals with all challenges of the Church and contemporary world. The man has his place in the center of contemporary theologically-pastoral reflexion ${ }^{19}$, but its base is Christian anthropology ${ }^{20}$.

However the greatest menace for that theologically-pastoral science about the God and the man is growth of contemporary rationalism which means radical contrast of the spirit and the body within a person ${ }^{21}$. A man in this kind of thinking stops to be a person and a subject and becomes exclusively an object. The conception of the man deformed by rationalism questions the dignity of a human being, for it says that that man's existence is completely determined and conditioned by outer factors of behavioral, cultural and psychological or environmental nature. This is why rationalism prefers such a freedom, understood in categories of absolute autonomy, that shall be the only one not undergoing any control, source of human's personal selection, and this way it shall serve him in self-confirmation at any price ${ }^{22}$.

The proper service to the poor and excluded man requires first to promote that man who is a person owing both; his body and his spirit ${ }^{23}$. His body is "soulful” and his spirit is so deeply united with his body, that may be called „soulful” spirit. The deepest source of its getting to know is the Word that became the Body, that is why the Christ manifests a man to the man ${ }^{24}$. Such teaching of the Vatican's Council II is a reply that the Church gives to the modern

\footnotetext{
19 Pastoral theology is deeply related to science about the man, for showing his dignity, freedom and destiny allow to organize pastoral care in a new light, where elimination of of any forces and methods including black-mail, menacing, promises with no base in the Church's practice and the Revelation. A.L. Safranski Kairology. „Church 's science nowadays” Lublin 1990, p. 20.

20 See Klosowski „Rules-Education-last will, Episteme 11 (2001).

21 The same philosopher that had said „I think, so I am” (Cogita ergo sum ) started the contemporary thinking of a man (at the same time), that is of dualistic nature.

22 John Paul II Apostol's Adhortation Pastores dabo vobis, 37.

23 Corpore et anima unus" (KDK 14).

${ }^{24}$ KDK 24.
} 
rationalism ${ }^{25}$. The Christ that manifests a man to the man also enables understanding and feeling of vocation as a free dialogue of love that starts when the God speaks to the man and reaches this goal when then gives himself in an unselfish gift ${ }^{26}$. Such truth allows to set the proper proportions between the sociological and theological poverty. The man, even the poor one needs authentic spiritual maturity that would help him to be "himself” and would make that he discovers hope in himself, that will initiate a natural optimism and a desire of a spiritual change in his life.

Such Vaticanum II teaching that says; „Our epoch needs wisdom more than previous times, such a wisdom that would make all new things, that a man discovers more human like", is very present in researches conducted in pastoral theology. "The future of the world will be in danger if people are not more wise"27. This considerable change, in both; science and didactic sphere that pastoral theology is facing means that all problems related to poverty and social exclusion may be solved by widely understood co-operation of scientists, practicians, particularly politicians, for whom every man ought to be the most important as well as the responsibility for his development.

The theology ought to first of all serve contemporary man's spiritual development and to accustom him to deeper understanding of the God's World ${ }^{28}$. However the theology may be useful to the man only when he gets to know it. John Paul II pointed the man as first way the Church ought to tend to in order to fulfill its mission ${ }^{29}$. The man is the first and the most fundamental way of the Church, for the Christ had appointed it himself, for it leads unchangeable through the Mystery of Redemption and Incarnation. "The man is such a way of the Church - that leads somehow at a base of all the ways, that

\footnotetext{
25 KDK 19.

26 John Paul II Apostol's 'Adhoration Pastores dubo vobis, 37.

27 KDK 15.

28 John Paul II Apostol's' Adhoration Ecclesia in europa,52.

29 See Goralczyk A man by the Church's way in John Paul II teaching, Warsaw pastoral Studio 5 (2007) p. 8-21.
} 
the Church should tend to, due to every man with no exception had been redeemed by the Christ, due to the Christ is somehow united to every man, even if the man had no idea about it" ${ }^{30}$. Theology is then on service of every man, however it is particularly addressed to the Christ's students, who are members of the Church's alive body.

This is why it is particularly necessary that Christians, enlightened and directed by faith, could get to know the real identity of church and its beauty and sanctity, and owing that they could love it as their own mother. Taking the above into consideration the real sensus Ecclesiae ought to be aroused, which is joined with inner awareness of being the Church that is the mystery of communion ${ }^{31}$.

Summing this up, it could be claimed, that church that is aware of its mission towards the man, may actively participate in solving problems related to poverty and social exclusion. However it ought to be emphasized that the Church's community cannot substitute democratic structures that are responsible for making conditions for fair goods' distribution. The Church ought to include itself in purification of justice, ideas through wise argumentation and also arise spiritual forces, without which the justice always demanding utterances, cannot consolidate and develop. Nevertheless church is deeply interested in the justice's dealing out through opening intelligence and the will on required goods $\mathrm{s}^{32}$.

\footnotetext{
Summary

The topic of this article is analyzing poverty and social exclusion in theological size. Next two thesis are described. First; the common source of poverty and social exclusion is shown, next; the effects resulting from it are presented. Within the next part of the article the role of pastoral theology in solving problems related to those occurrences is shown. In the final conclusion there is a statement that fair nation cannot be an act of the Church, yet

30 John Paul II Enciclices Redemptor hominis,14.

31 John Paul II Manifest to participants of the World's Laic Catholics Congress; you are Christ's witnesses in new millennium, Rome 21 XI 2000, 4.

32 Benedict XVI Enciclics Deus Caritas est, 28 a.
} 
ought to be pursued by politics. Church, however, is broadly interested in pursuing justice through intelligence and the will of contemporary people for demanding of the good.

Key words: poverty, social exclusion, the man, justice, effects and results, pastoral theology, politics, the Church.

ks. Jan Przybyłowski (ur. 1958), kapłan diecezji włocławskiej, profesor zwyczajny. Studia specjalistyczne w zakresie teologii pastoralnej ukończył na Katolickim Uniwersytecie Lubelskim, otrzymując stopień doktora w 1993 roku. Habilitację uzyskał na Uniwersytecie Kardynała Stefana Wyszyńskiego (UKSW) w Warszawie w 2001 roku. Tytuł naukowy profesora nauk teologicznych otrzymał 25 stycznia 2011 roku. Od 2002 roku jest kierownikiem Katedry Teologii Pastoralnej i Nauk Pomocniczych na UKSW. W latach 20082010 pełnił funkcję prodziekana ds. naukowych na Wydziale Teologicznym UKSW, a w latach 2010-2012 był prorektorem ds. finansowych i naukowych na UKSW. Jest autorem kilkudziesięciu artykułów naukowych i kilku książek, m.in. „Znaczenie nowej ewangelizacji dla duszpasterstwa młodzieży. Studium pastoralne” (Lublin 2001); „Funkcja wychowawcza w teorii i praktyce eklezjalnej. Studium teologicznopastoralne” (Warszawa 2010); „Jak modli się polska młodzież? Studium socjologiczne”, Warszawa 2013.

\section{Bibliografia}

D. Zalewska, Ubóstwo. Teorie, badania, Warszawa 1997

Skazani na wykluczenie, red. M. Orłowska, Warszawa 2005

A. Radziewicz - Winnicki, Emeryci i renciści wobec sytuacji społecznego ubóstwa, Katowice 1997

Social Exclusion in European Welfare States, red. R. Muffels, P. Tsakloglou, D.G. Mayes, Edward Elgar 2002

J. Sztumski, Ubóstwo jako problem społeczny, „Polityka Społeczna” 8(1995)

M. Kabaj, Program przeciwdziałania ubóstwu i bezrobociu. Raport IP i SS (nr 19), Warszawa 2000

T. Kowalak, E. Leś, Kwestia ubóstwa, w: Polityka społeczna, red. A. Rajkiewicz, Warszawa 1996

Welfare Policy from Below. Struggles Against Social Exclusion in Europe, red. H. Steinert, A. Pilgram, Ashgate 2003

L. Beskid, Postrzeganie biedy przez polskie społeczeństwo, „Polityka Społeczna” 8(1995) 
K.W., Frieske, Bieda - miary i interpretacje, w: Polska bieda II. Kryteria. Oceny. Przeciwdziałanie, red. S. Golinowska, Warszawa 1997

Policy Responses to Social Exclusion, red. J. Percy-Smith, Open University Press 2000

R. Kraczla, Badania nad ubóstwem. Przeglad głównych nurtów i teorii, w: $W$ kręgu ubóstwa. Próba analizy psychospołecznych aspektów zjawiska, red. K. Wódz, Katowice 1993

R. Lister, Bieda, Warszawa 2007

J. Grotowska-Leder, Fenomen wielkomiejskiej biedy. Od epizodu do underclass, Łódź 2002

R.W., Maris, Social Problems, Chicago 1988

J. Hills, J. Le Grand, D. Piachaud, Understanding Social Exclusion, Oxford University Press 2002

L. Miś, Teoria socjologiczna a praktyka rozwiązywania problemów społecznych, w: Problemy społeczne w okresie zmian systemowych w Polsce, red. M. Malikowski, Rzeszów 1997

M. K., Mlicki, Procesy identyfikacji problemów społecznych, w: Socjologia problemów społecznych. Teorie i rzeczywistość, Wrocław 1987

W. Warzywoda-Kruszyńska, Unia Europejska wobec problemów biedy i wykluczenia społecznego, w: Prawo dziecka do godziwych warunków socjalnych, Warszawa 2002 